\title{
The effect of gluten-free diet on Th1--Th2--Th3- associated intestinal immune responses in celiac disease
}

\author{
Anne Lahdenperä, Johnny Ludvigsson, Karin Fälth-Magnusson, \\ Lotta Högberg and Outi Vaarala
}

\section{Linköping University Post Print}

\section{Tweet}

N.B.: When citing this work, cite the original article.

Original Publication:

Anne Lahdenperä, Johnny Ludvigsson, Karin Fälth-Magnusson, Lotta Högberg and Outi Vaarala, The effect of gluten-free diet on Th1--Th2--Th3-associated intestinal immune responses in celiac disease, 2011, SCANDINAVIAN JOURNAL OF GASTROENTEROLOGY, (46), 5, 538-549.

http://dx.doi.org/10.3109/00365521.2011.551888

Copyright: Informa Healthcare http://informahealthcare.com/

Postprint available at: Linköping University Electronic Press http://urn.kb.se/resolve?urn=urn:nbn:se:liu:diva-67826 


\title{
The effect of gluten-free diet on Th1-Th2-Th3-associated intestinal immune responses in celiac disease
}

\author{
Anne Lahdenperä ${ }^{\mathbf{1}}$, Johnny Ludvigsson ${ }^{\mathbf{1}}$, Karin Fälth-Magnusson ${ }^{\mathbf{1}}$, Lotta Högberg 1, $\mathbf{2}$, \\ Outi Vaarala ${ }^{1,3}$
}

${ }^{1}$ Division of Paediatrics, Department of Clinical and Experimental Medicine, Faculty of Health Sciences, Linköping University, Linköping, Sweden.

${ }^{2}$ Paediatric Clinic, Norrköping Hospital, Norrköping, Sweden.

${ }^{3}$ Department of Vaccines and Immune Protection, Immune Response Unit, National Institute for Health and Welfare, Helsinki, Finland.

\author{
Anne Lahdenperä \\ Clinical Experimental Research \\ Division of Paediatrics \\ Faculty of Health Sciences \\ Linköping University \\ S-581 85 Linköping \\ Sweden \\ Phone: +46-(0)10-103 3565 \\ Fax: +46-(0)13-12 7465 \\ e-mail: anne.lahdenpera@liu.se
}

Key words: Celiac disease, children, biopsies, PBMC, gluten-free diet, gene expression, arrays, Th1, Th2. 


\section{Abstract}

\section{Objective:}

To study T-helper (Th)1-Th2-Th3 gene activation profile in the small intestine and peripheral blood of children with celiac disease (CD) with special interest in the response to the gluten-free diet (GFD) treatment in order to elucidate an immune dysregulation not triggered by gluten.

\section{Material and Methods:}

Small intestinal biopsies and venous blood were taken from 7 children with CD (mean age: 8 years, 4 girls) at presentation and after one year of strict GFD. The Th1-Th2-Th3 gene expression profile was examined by Real-time-PCR-arrays. The findings were compared to the corresponding expressions in peripheral blood and small intestinal biopsies from 6 reference children without CD (mean age: 6 years, 4 girls).

\section{Results:}

The Th1 gene expression profile including interferon (IFN)- $\gamma$, signal transducer and activator of transcription (STAT) 1 and interferon regulatory factor (IRF) 1 together with reduced interleukin (IL)-2 expression was pronounced in small intestinal biopsies from children with untreated CD. A down-regulation of IFN- $\gamma$ transcripts was seen after one year of GFD, but there was still increased expression of STAT1 and IRF1 in association with low IL-2 expression in spite of eliminated exposure to wheat gluten. In contrast, the decreased intestinal expression of Th2 gene markers observed at presentation were normalised with GFD. The alterations in the mucosal gene expression profile were not reflected in peripheral blood.

\section{Conclusion:}


The GFD did not correct the increased activation of the IFN- $\gamma$ signalling pathway related markers and reduced IL-2 expression, suggesting that they represent an immune dysregulation not dependent on gluten exposure.

Keywords: Celiac disease, children, biopsies, PBMC, gluten free diet, gene expression, arrays, Th1, Th2. 


\section{Introduction}

Celiac disease (CD) is a common autoimmune disorder, which develops in genetically predisposed/susceptible individuals (HLA-DQ2/DQ8 positive) as a result of intolerance to dietary gluten. The disease is characterised by mucosal villous atrophy with crypt hyperplasia, and immune cell infiltration in the small intestinal mucosa causing severe inflammation. Treatment of CD consists of a lifelong gluten-free diet (GFD), which causes clinical improvement and normalisation of the mucosal villous atrophy, including improvement of the intestinal inflammation. T-cells reacting against transglutaminase deamidated gliadin have been reported to be interferon (IFN)- $\gamma$ secreting cells emphasising the role of T-helper (Th) 1 response in the pathogenesis [1]. The exact mechanism by which gluten damages the intestinal mucosa is unknown. IFN- $\gamma$ alters the epithelial barrier function [2] and both IFN- $\gamma$ and tumor necrosis factor (TNF)- $\alpha$ have been shown to increase intestinal permeability by disruption of tight junctions [3].

The small intestinal inflammation in untreated CD is characterised by increased numbers of intraepithelial lymphocytes (IEL), lamina propria lymphocytes (LPL) and dendritic cells [4-6]. The intestinal immune cells in CD produce IFN- $\gamma$ and TNF- $\alpha[4,7,8]$, which are believed to be involved in the pathogenesis. The janus kinase - signal transducer and activator of transcription (JAK-STAT) pathway, which mediates a Th1 (IFN- $\gamma$ ) response through activation of STAT proteins, has been reported to be of importance in the CD pathogenesis [7,9]. Apart from IFN- $\gamma$, also other cytokines as IFN- $\alpha / \beta$, interleukin (IL) 6 , TNF- $\alpha$ and transforming growth factor (TGF)- $\beta$ that can activate or cross-talk with the JAK-STAT signalling pathway are suggested to be of importance in CD [10,11].

A dysregulated intestinal immune system is regarded as a plausible cause of the aberrant immune response against the transglutaminase modified gliadin peptide(s). In healthy mucosa transglutaminase modified gliadin peptides are tolerated and do not trigger intestinal inflammation in the majority of individuals who carry the $\mathrm{CD}$ related risk genotype. Thus, the intestinal 
dysregulation that results in full-blown CD likely also depends on other factors than gluten exposure, which makes it reasonable not to expect full normalisation whendietary gluten is removed. Follow-up biopsies taken after GFD treatment is no longer used as routine in diagnosing $\mathrm{CD}$, hence it is very difficult to study a possible underlying immune dysregulation related to $\mathrm{CD}$, i.e. not caused by the dietary gliadin. In Sweden we followed the effects of GFD with follow-up biopsies until recently, and thereby have a unique opportunity to compare the intestinal immune reaction in patients untreated and after treatment with GFD.

In this study we have analysed the expression pattern of Th1-Th2-Th3 associated genes in the small intestine and in the peripheral blood from children with CD before and after one - year of treatment with GFD. 


\section{Method}

\section{Study population}

Small intestinal biopsy specimens and venous blood were obtained from 7 children with CD (mean age: 8 years, range: $2-13$ years, 4 girls $\& 3$ boys), both before and after 1 year of strictly GFD (Table 1). All of the studied children were under investigation for suspected CD at the Paediatric Clinic, University Hospital Linköping or at the Paediatric Clinics in Norrköping or Motala. They had undergone an initial small intestinal biopsy, which showed a typical morphological picture suggesting CD and the second biopsy after one - year of strict GFD demonstrated improvement /normalisation of the mucosa.

For reference, we studied small intestinal biopsy specimens and venous blood from 6 reference children (mean age: 6 years (range: $1-11$ years), 4 girls $\& 2$ boys) who performed a small intestinal biopsy due to a suspicion of $\mathrm{CD}$, but who displayed a morphologically normal mucosa (Table 1). The reference children were all on a normal diet containing gluten.

\section{Preparation of PBMC \& biopsies}

Venous blood samples were drawn into heparin treated tubes (Vacuette, Greiner Labortechnik, Kremsmünster, Austria). Peripheral blood mononuclear cells (PBMC) were separated on Ficoll Paque Density gradient (Amersham, Pharmacia, Biotech, Uppsala, Sweden) according to standardised methodology and cryopreserved in freezing medium (50\% fetal calf serum, 40\% RPMI 1640 and 10\% DMSO) (Sigma-Aldrich, Stockholm, Sweden). After thawing of the PBMC, the cell viability was checked with Trypan blue (Sigma-Aldrich) exclusion test. The cells were washed in cold $\left(4^{\circ} \mathrm{C}\right)$ PBS and lysed using RLT lysis buffer (Qiagen, Hilden, Germany) with $\beta$-ME (Sigma, Stockholm, Sweden). Small intestinal biopsy specimens were divided for routine histology and the 
surplus was used for PCR-array studies. At surgery, the biopsies were immediately placed in RPMImedium, transported to the laboratory, snap-frozen and cryopreserved in $\mathrm{N}_{2}$.

\section{RNA preparation}

Total RNA was isolated from the PBMC-lysates using QIA shredders (Qiagen, Hilden, Germany) and RNeasy® Mini Kit (Qiagen), including on column DNase treatment with RNase-Free DNase Set (Qiagen), according to the manufacturer's guidelines. Similarly, total RNA was isolated from cryopreserved biopsy specimens by homogenisation using Stainless Steel Beads, Tissue Lyser II (Qiagen) and RNeasy® Mini Kit (Qiagen) including on column DNase treatment with RNase-Free DNase Set (Qiagen), according to the manufacturer's guidelines. The RNA quality and quantity was checked with RNA 6000 Nano LabChip® Kit (Agilent Technologies, Palo Alto, CA, USA) on an Agilent 2100 Bioanalyzer (Agilent Technologies), according to the manufacturer's guidelines.

\section{RT-PCR and Real-time-PCR-arrays}

Reverse transcription of $1 \mu \mathrm{g}$ total RNA into first strand cDNA was performed with the RT2 PCRarray First strand Kit (SuperArray, Gaithersburg, MD, USA), according to the manufacturer's guidelines. In brief, DNase treatment $\left(42^{\circ} \mathrm{C}\right.$ for $\left.5 \mathrm{~min}\right)$ and reverse transcription was performed $\left(42^{\circ} \mathrm{C}\right.$ for $15 \mathrm{~min}$ followed by $95^{\circ} \mathrm{C}$ for $\left.5 \mathrm{~min}\right)$.

A PCR cocktail, containing: RT2 Real-Time SYBR®Green/ROX qPCR Master Mix (containing HotStart DNA polymerase, SYBR®Green dye, and ROX reference dye) (SuperArray), doubledistilled $\mathrm{H}_{2} \mathrm{O}$ and cDNA, was loaded in each of the 96 wells of the Human Th1-Th2-Th3 RT ${ }^{2}$ ProfilerTM PCR Array (PAHS-034, SuperArray). PCR amplification was performed, by ABI 7500 Fast Real-Time-PCR System (Applied Biosystems, Foster City, CA, USA), with an initial 10-min step at $95^{\circ} \mathrm{C}$ followed by 40 cycles of $95^{\circ} \mathrm{C}$ for $15 \mathrm{~s}$ and $60^{\circ} \mathrm{C}$ for $1 \mathrm{~min}$. Baseline and threshold values were set manually, using the 7500 System Software (Applied Biosystems), and were the 
same across all PCR-array runs in the same analysis, according to the producer's recommendations. Only genes with threshold cycle $(\mathrm{Ct})$-values $<35$ were considered to be detectable (due to the low copy numbers of the genes in samples with Ct-values $>35$ ), according to the manufacturer's guidelines. The Ct-values were normalised with the average Ct-value of all (five) housekeeping genes $(\mathrm{HKG})$ on the array: Beta-2-microglobulin (B2M), Hypoxanthine phosphoribosyltransferase 1 (HPRT1), Ribosomal protein L13a (RPL13A), Glyceraldehyde-3-phosphate dehydrogenase

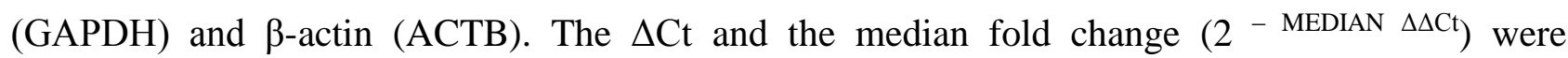
calculated for the genes on the array.

\section{Statistics}

Statistical analysis was performed using the SPSS for Windows version 14.0 (SPSS, Chicago, USA). Wilcoxon signed ranks test was used to compare gene expression responses ( $\Delta$ Ct-values) in PBMC and biopsies from children with CD, before and after treatment with GFD. Mann-Whitney U test was used to compare gene expression responses ( $\triangle \mathrm{Ct}$-values) in PBMC and biopsies between children with $\mathrm{CD}$ and reference children. P-values $<0.05$ were considered significant.

A cut off criterium for the gene expression fold change $\left(2^{- \text {MEDIAN } \Delta \Delta \mathrm{Ct})}\right.$ between the samples was used; for induction a fold change of 1.4 and for repression a fold change of -1.4 was considered to be of biological importance. We considered the difference in the gene expression level between the groups significant if both criteria fold change and group comparison by Wilcoxon (follow-up samples) or Mann-Whitney U test was significant $(\mathrm{p}<0.05)$.

In order to disclose multivariate responses Principal Component Analysis (PCA) of the HKGnormalised Real-time-PCR-array data was employed, using GeneEx (MultiD Analyses/TATAA Biocenter, Gothenburg, Sweden). The data was pre-processed by calculating the relative expression of the genes, log2-transformation and mean-centering. Genes passing the double cut-off criteria; the fold change cut-off together with a significant difference in gene expression between the study 
groups (Mann-Whitney or Wilcoxon $\mathrm{p}<0.05$; between Untreated-CD and/or GFD-treated-CD and/or Reference), were visualised with PCA.

\section{Ethics}

The study was approved by the Regional Ethics Committee for Human Research at the University Hospital of Linköping and written informed consent was obtained from the families. 


\section{Results}

Detectable PCR products (<35 cycles) were obtained from the majority of the 84 Th1-Th2-Th3 genes on the array (Supplementary table 1). The expression level of 14 genes in biopsies and 9 genes in PBMC were lower than the established detection level $(<35$ cycles) in the majority of the study subjects and were therefore excluded from the statistical analyses (Supplementary table 1).

\section{Expression of Th1-Th2-Th3 genes in small intestinal biopsies after GFD}

Not normalised by GFD

Increased expression of Th1 response related genes IFN- $\gamma$, STAT1 and IRF1 together with decreased expression of IL-2 was found in children with CD (Figure 1 and Supplementary table 2a). After the GFD treatment the expression of the Th1 pathway related genes IFN- $\gamma$, STAT1 and interferon regulatory factor (IRF) 1 was down-regulated in comparison to the levels seen before treatment. However, the fold change in the expression level of IFN- $\gamma$, STAT1 and IRF1 in small intestinal biopsies taken after GFD was still above 1.4 when compared to the biopsies from the control children. The expression level of STAT1 after GFD remained significantly higher in patients than in reference children (fold change 1.78 and $\mathrm{p}=0.04$ ). Thus, the high Th1 response seen in untreated CD children decreased after the GFD-treatment, but remained higher than in non-CD children. Also the intestinal IL-2, CD80 and inducible T-cell co-stimulator (ICOS) expression remained low in children with CD after GFD treatment (Supplementary table 2a, Figure 3a). On the other hand, the glomulin (GLMN) expression remained high in patients compared to reference children even after GFD (Supplementary table 2a, Figure 3c).

\section{Normalised by GFD}

As response to GFD, the expression of Th2 related genes, such as IL-4R, IL-13RA1, IL-5, STAT6 as well as JAK1 and MAF, increased in the patients, and no differences were seen between treated CD children and the reference group (Supplementary table 2a, Figure 3b). The decreased expression 
of IL-18, CREB binding protein (CREBBP) and TGF- $\beta 3$ at diagnosis was normalised with GFD (Supplementary table 2a, Figure 3b).

\section{Expression of Th1-Th2-Th3 genes in PBMC, the peripheral circulation}

In contrast to the observations noted in the biopsies, the expression of the altered mucosal Th1 or Th2 markers did not differ between PBMCs from CD and reference children. Instead, increased expression of other Th1 related genes, such as T-box 21 (TBX21) transcription factor and STAT4 were noted in the peripheral blood mononuclear cell population from children with $\mathrm{CD}$, both at diagnosis and after GFD, when compared to the reference children (Supplementary table 2b). Children with CD had down regulated ICOS and suppressor of cytokine signalling (SOCS) 1 expression both at diagnosis and after GFD-treatment (Supplementary table 2b).

A high expression of chemokine ligand 5 (CCL5), IL-15, IL-18, IL-18R was seen in PBMC in untreated $\mathrm{CD}$ children compared to the reference children, and this high expression was not affected by the GFD (Supplementary table 2b, Figure 3a). Additionally, children with untreated CD had increased levels of fas ligand (FASL), G protein-coupled receptor 44 (GPR44) and MAF compared to the reference group. The GPR44 expression remained elevated after the GFD-treatment (Supplementary table 2b).

The expression of TNFSFR9 and MAPK8 were elevated in PBMCs (from untreated) from CD children both before and after GFD-treatment in comparison to non-CD children (Supplementary table 2b). 
Multivariate analysis of intestinal and peripheral immune responses with PCA

PCA visualisation of the genes with significant differences (fold change and $p \leq 0.05$ ) in intestinal and peripheral expression ( 20 and 17 genes, respectively), revealed separation between the three study groups: untreated-CD, GFD-treated-CD and references (Figure 4 and Figure 5, respectively). 


\section{Discussion}

We followed the immune activation stage in the intestinal biopsies from CD-children taken at presentation and after a year of GFD treatment and evaluated whether the intestinal immune dysregulation remains after gluten removal. This dysregulation observed after GFD which results in mucosal healing should reasonably depend on other factors than gluten, which may be important in the development of intolerance to gluten and CD.

Real-time-PCR-arrays were used to study the Th1-Th2-Th3 gene expression profiles in small intestinal biopsies and PBMC from children with CD. The method combines Real-time-PCR and microarray technology, yielding a sensitive method to study many genes simultaneously. The PCRarray system yields high positive call rates and has a high reproducibility [12], which was confirmed in our study where the majority of the 84 genes were detectable. In our study, the five house keeping genes included on the array were used for normalisation of the 84 Th1-Th2-Th3 genes $[12,13]$ and fold-change cut-off values were used for altered expression levels as has previously been described [12,14-17].

As expected we found that the Th1 expression profile including IFN- $\gamma$, STAT1 and IRF1 was pronounced in the small intestinal biopsies from untreated children with CD. Although GFD for one year did down regulate these markers the expression of STAT1 and IRF1 genes were still elevated in treated children with CD compared to reference children. The findings in our study are in agreement with previous reports of the increased intestinal IFN- $\gamma$ and STAT1 expression in untreated CD both at RNA and protein level [7,9,18-22]. Further, IRF1 which is involved in IFN- $\gamma$ $[23,24]$ and TNF mediated responses [25] via regulation of the induction of NO/iNOS in macrophages $[24,26]$ has previously been reported to be elevated at RNA and protein level in biopsies from untreated CD children [18]. The novelty of our study is the fact that we show persistent activation of the Th1 (IFN- $\gamma)$ signalling pathway markers STAT1 and IRF1 in the small 
intestine of CD children despite GFD treatment. This suggests that STAT1 and IRF1 are associated with a basic dysregulation of the immune system resulting in the gliadin intolerance. STAT1 and IRF1 has not previously been studied in GFD treated CD children, but our results strengthen the observation by Forsberg et al indicating that intraepithelial T lymphocytes in treated, symptom-free CD patients display increased IFN- $\gamma$ levels compared with controls [8]. Our results extend these findings to include the IFN- $\gamma$ down stream signalling related marker STAT1.

Further, the down regulated intestinal IL-2 response in our study was not affected by the GFD treatment. This indicates that the IL-2 deficient environment is part of an immune dysregulation which leads to altered responses to dietary gliadin. Decreased intestinal IL-2 expression in CD patients has previously been reported by other groups [8]. The function of regulatory T-cells, which express high level of IL-2R, is dependent on IL-2 and TGF- $\beta$. Accordingly, low expression of IL-2 in the CD mucosa could indicate conditions in which the function of regulatory T-cells is impaired. The function of ICOS is also dependent on the presence of IL-2 [27]. It has been shown that the function of regulatory T-cells is dependent on ICOS in insulitis [28]. In humans it has been shown that ICOS supports differentiation of Tregs when co-stimulatory signals are sub-optimal [29]. Interestingly, in parallel with the reduction of IL-2 we found a trend for reduced expression of ICOS after GFD-treatment in the intestine. Also, the expression of the co-stimulatory molecule CD80 was decreased. Since these factors were not corrected by GFD they may represent so-called intrinsic factors related to the development of CD. The dysfunction of the IL-2-ICOS-Treg pathway in CD is supported by findings of ICOS gene polymorphism in association with CD susceptibility $[30]$.

We also found a down regulation of the expression of Th2 associated markers, IL-18 and CREBBP in the small intestinal biopsies of children with $\mathrm{CD}$, but all these markers were normalised with GFD. CREBBP may indicate a hypoxic environment in the intestinal epithelium [31,32], and a Th2 
down-regulation at presentation of $\mathrm{CD}$ likely reflects the reciprocal regulation of $\mathrm{Th} 2$ response by Th1 related cytokines.

Unsupervised multivariate exploratory analysis techniques e.g. PCA and cluster analysis are commonly used for analysis and visualisation of complex data sets such as expression array data $[33,34]$, even though their emphasis not is the use of statistical cut-off values. In our study the PCA confirmed the results from the "traditional statistics", since the genes passing the double cut-off criteria for significant gene expression separated the study groups in the PCA-plots. Furthermore, the PCA also revealed that the intestinal and peripheral samples separated the study groups differently.

The small intestinal biopsies were taken from the participating children due to suspected CD. Three of the children were TGA-positive and thereby had high risk of $\mathrm{CD}$, and two of them developed CD two years later. Two reference children were IgA-deficient and showed highest expression of Th1 genes among reference children. Accordingly, the findings of increased expression of Th1 gene markers in children with treated CD should not be enhanced but rather decreased when these children with potential CD and IgA deficiency were included in the reference group. It is also possible that normalisation of the intestinal Th1 and impaired IL-2 expression takes longer time than one year after elimination of dietary gluten. The normalisation of TGA was however seen in 6 of 7 patients as well as mucosal healing and other intestinal alterations, such as decreased Th2 gene expression profile, were normalised during the follow-up.

We are aware of the methodological limitations using whole biopsies, which unables studies of distinct cell responses/types. However, the gene expression profiles presented in our study reflects the complex disease related network of Th1-Th2-Th3 related factors in the intestine. Comparison of the local and peripheral gene expression profiles in $\mathrm{CD}$ revealed that the alteration of Th1, Th2 and 
Th3 associated markers in the intestinal biopsies was generally not reflected in peripheral blood, which puts studies of peripheral blood in tissue-specific immune diseases in question.

However, some of our results seen in peripheral blood warrant further discussion. Increased expression levels of IL-15 and IL-18 reflect activation of innate immunity in the periphery. It has been suggested that IL-15 contributes to the inflammatory response in CD by inhibition of TGF- $\beta$ signalling in mucosal $\mathrm{T}$ cells [35]. Thus, it is not excluded that the mucosal inflammation is potentiated by systemic factors.

An interesting finding was the observed up-regulation of the GLMN expression both in the intestine and in peripheral blood samples of untreated and GFD-treated children with CD. The simultaneous up-regulation of GLMN in the blood and in the intestine of CD children suggests that GLMN is closely related to $\mathrm{CD}$ and not only triggered by dietary gliadin. Little is known about the role of GLMN, also called FAP48, in humans. Over expression of glomulin in Jurkat T-cell lines has been reported to lead to discrepant findings such as inhibition of proliferation and, on the other hand, augmentation of IL-2 production in activated T-cells [36]. Thus, further studies are needed to examine a possible role of GLMN in CD.

\section{Conclusions}

Decreased IL-2 and CD80 expression together with high intestinal Th1 and low Th2 responses were characteristics of the local inflammation in untreated CD with villous atrophy. The GFD caused a normalisation of the intestinal Th2 responses, but did not correct the impaired IL-2 or increased activation of the IFN- $\gamma$ pathway related molecules. Presumably, these are features of an immune dysregulation in CD which is not dependent on gluten exposure. The intestinal Th1-Th2-Th3 immune responses were not reflected in the peripheral blood for most genes studied. 


\section{Acknowledgements}

We thank all children that participated in the study. Lars Stenhammar, Pia Laurin, Louise Forslund and Maria Nordwall at the Paediatric Clinics in Linköping, Norrköping and Motala are acknowledged for the clinical support. The research nurses at the Division of Paedatrics in Linköping, Norrköping and Motala and the laboratory technicians Gosia Konefal and Ingela Johansson are also thanked for the help with the sample collection. Rosaura Casas is acknowledged for her considerable input in preparation of the manuscript. This work was generously supported by

the County Council of Östergötland, Barndiabetesfonden and the Swedish Research Council (20084051). 


\section{References}

[1] Bodd M, Raki M, Tollefsen S, Fallang LE, Bergseng E, Lundin KE, et al. HLA-DQ2restricted gluten-reactive T cells produce IL-21 but not IL-17 or IL-22. Mucosal Immunol 2010;3; 594-601.

[2] Adams RB, Planchon SM, Roche JK. IFN-gamma modulation of epithelial barrier function. Time course, reversibility, and site of cytokine binding. J Immunol 1993;150:2356-2363.

[3] Bruewer M, Luegering A, Kucharzik T, Parkos CA, Madara JL, Hopkins AM, et al. Proinflammatory cytokines disrupt epithelial barrier function by apoptosis-independent mechanisms. J Immunol 2003;171:6164-6172.

[4] Kontakou M, Sturgess RP, Przemioslo RT, Limb GA, Nelufer JM, Ciclitira PJ. Detection of interferon gamma mRNA in the mucosa of patients with coeliac disease by in situ hybridisation. Gut 1994;35:1037-1041.

[5] Di Sabatino A, D'Alo S, Millimaggi D, Ciccocioppo R, Parroni R, Sciarra G, et al. Apoptosis and peripheral blood lymphocyte depletion in coeliac disease. Immunology 2001;103:435-440.

[6] Di Sabatino A, Pickard KM, Gordon JN, Salvati V, Mazzarella G, Beattie RM, et al. Evidence for the role of interferon-alfa production by dendritic cells in the Th1 response in celiac disease. Gastroenterology 2007;133:1175-1187.

[7] Monteleone I, Monteleone G, Del Vecchio Blanco G, Vavassori P, Cucchiara S, MacDonald TT, et al. Regulation of the T helper cell type 1 transcription factor T-bet in coeliac disease mucosa. Gut 2004;53:1090-1095.

[8] Forsberg G, Hernell O, Melgar S, Israelsson A, Hammarstrom S, Hammarstrom ML. Paradoxical coexpression of proinflammatory and down-regulatory cytokines in intestinal $\mathrm{T}$ cells in childhood celiac disease. Gastroenterology 2002;123:667-678. 
[9] Mazzarella G, MacDonald TT, Salvati VM, Mulligan P, Pasquale L, Stefanile R, et al. Constitutive activation of the signal transducer and activator of transcription pathway in celiac disease lesions. Am J Pathol 2003;162:1845-1855.

[10] Shuai K, Liu B. Regulation of JAK-STAT signalling in the immune system. Nat Rev Immunol 2003;3:900-911.

[11] Diosdado B, Monsuur AJ, Mearin ML, Mulder C, Wijmenga C. The downstream modulator of interferon-gamma, STAT1 is not genetically associated to the Dutch coeliac disease population. Eur J Hum Genet 2006;14:1120-1124.

[12] Arikawa E, Sun Y, Wang J, Zhou Q, Ning B, Dial SL, et al. Cross-platform comparison of SYBR Green real-time PCR with TaqMan PCR, microarrays and other gene expression measurement technologies evaluated in the MicroArray Quality Control (MAQC) study. BMC Genomics 2008;9:328.

[13] Hansel NN, Cheadle C, Diette GB, Wright J, Thompson KM, Barnes KC, et al. Analysis of CD4+ T-cell gene expression in allergic subjects using two different microarray platforms. Allergy 2008;63:366-369.

[14] Veeriah S, Miene C, Habermann N, Hofmann T, Klenow S, Sauer J, et al. Apple polyphenols modulate expression of selected genes related to toxicological defence and stress response in human colon adenoma cells. Int J Cancer 2008;122:2647-2655.

[15] L'Esperance S, Bachvarova M, Tetu B, Mes-Masson AM, Bachvarov D. Global gene expression analysis of early response to chemotherapy treatment in ovarian cancer spheroids. BMC Genomics 2008;9:99.

[16] Maillard CM, Bouquet C, Petitjean MM, Mestdagt M, Frau E, Jost M, et al. Reduction of brain metastases in plasminogen activator inhibitor-1-deficient mice with transgenic ocular tumors. Carcinogenesis 2008;29:2236-2242.

[17] Altman RB, Raychaudhuri S. Whole-genome expression analysis: challenges beyond clustering. Curr Opin Struct Biol 2001;11:340-347. 
[18] Salvati VM, MacDonald TT, Bajaj-Elliott M, Borrelli M, Staiano A, Auricchio S, et al. Interleukin 18 and associated markers of T helper cell type 1 activity in coeliac disease. Gut 2002;50:186-190.

[19] Tiittanen M, Westerholm-Ormio M, Verkasalo M, Savilahti E, Vaarala O. Infiltration of forkhead box P3-expressing cells in small intestinal mucosa in coeliac disease but not in type 1 diabetes. Clin Exp Immunol 2008;152:498-507.

[20] Juuti-Uusitalo K, Maki M, Kaukinen K, Collin P, Visakorpi T, Vihinen M, et al. cDNA microarray analysis of gene expression in coeliac disease jejunal biopsy samples. J Autoimmun 2004;22:249-265.

[21] Lahat N, Shapiro S, Karban A, Gerstein R, Kinarty A, Lerner A. Cytokine profile in coeliac disease. Scand J Immunol 1999;49:441-446.

[22] Wapenaar MC, van Belzen MJ, Fransen JH, Sarasqueta AF, Houwen RH, Meijer JW, et al. The interferon gamma gene in celiac disease: augmented expression correlates with tissue damage but no evidence for genetic susceptibility. J Autoimmun 2004;23:183-190.

[23] Lohoff M, Mittrucker HW, Prechtl S, Bischof S, Sommer F, Kock S, et al. Dysregulated T helper cell differentiation in the absence of interferon regulatory factor 4. Proc Natl Acad Sci U S A 2002;99:11808-11812.

[24] Martin E, Nathan C, Xie QW. Role of interferon regulatory factor 1 in induction of nitric oxide synthase. J Exp Med 1994;180:977-984.

[25] Yarilina A, Park-Min KH, Antoniv T, Hu X, Ivashkiv LB. TNF activates an IRF1dependent autocrine loop leading to sustained expression of chemokines and STAT1dependent type I interferon-response genes. Nat Immunol 2008;9:378-387.

[26] Kamijo R, Harada H, Matsuyama T, Bosland M, Gerecitano J, Shapiro D, et al. Requirement for transcription factor IRF-1 in NO synthase induction in macrophages. Science 1994;263:1612-1615. 
[27] Mesturini R, Nicola S, Chiocchetti A, Bernardone IS, Castelli L, Bensi T, et al. ICOS cooperates with CD28, IL-2, and IFN-gamma and modulates activation of human naive CD4+ T cells. Eur J Immunol 2006;36:2601-2612.

[28] Herman AE, Freeman GJ, Mathis D, Benoist C. CD4+CD25+ T regulatory cells dependent on ICOS promote regulation of effector cells in the prediabetic lesion. J Exp Med 2004;199:1479-1489.

[29] Akbari O, Freeman GJ, Meyer EH, Greenfield EA, Chang TT, Sharpe AH, et al. Antigenspecific regulatory T cells develop via the ICOS-ICOS-ligand pathway and inhibit allergeninduced airway hyperreactivity. Nat Med 2002;8:1024-1032.

[30] Haimila K, Smedberg T, Mustalahti K, Maki M, Partanen J, Holopainen P. Genetic association of coeliac disease susceptibility to polymorphisms in the ICOS gene on chromosome 2q33. Genes Immun 2004;5:85-92.

[31] Taylor CT. Regulation of intestinal epithelial gene expression in hypoxia. Kidney Int $2004 ; 66: 528-531$.

[32] O'Reilly SM, Leonard MO, Kieran N, Comerford KM, Cummins E, Pouliot M, et al. Hypoxia induces epithelial amphiregulin gene expression in a CREB-dependent manner. Am J Physiol Cell Physiol 2006;290:C592-600.

[33] Gerling IC, Singh S, Lenchik NI, Marshall DR, Wu J. New data analysis and mining approaches identify unique proteome and transcriptome markers of susceptibility to autoimmune diabetes. Mol Cell Proteomics 2006;5:293-305.

[34] Wu J, Lenchik NI, Gerling IC. Approaches to reduce false positives and false negatives in the analysis of microarray data: applications in type 1 diabetes research. BMC Genomics 2008;9 Suppl 2:S12.

[35] Benahmed M, Meresse B, Arnulf B, Barbe U, Mention JJ, Verkarre V, et al. Inhibition of TGF-beta signaling by IL-15: a new role for IL-15 in the loss of immune homeostasis in celiac disease. Gastroenterology 2007;132:994-1008. 
[36] Krummrei U, Baulieu EE, Chambraud B. The FKBP-associated protein FAP48 is an antiproliferative molecule and a player in T cell activation that increases IL2 synthesis. Proc Natl Acad Sci U S A 2003;100:2444-2449. 


\section{Figures}

Fig. 1

Intestinal gene expression
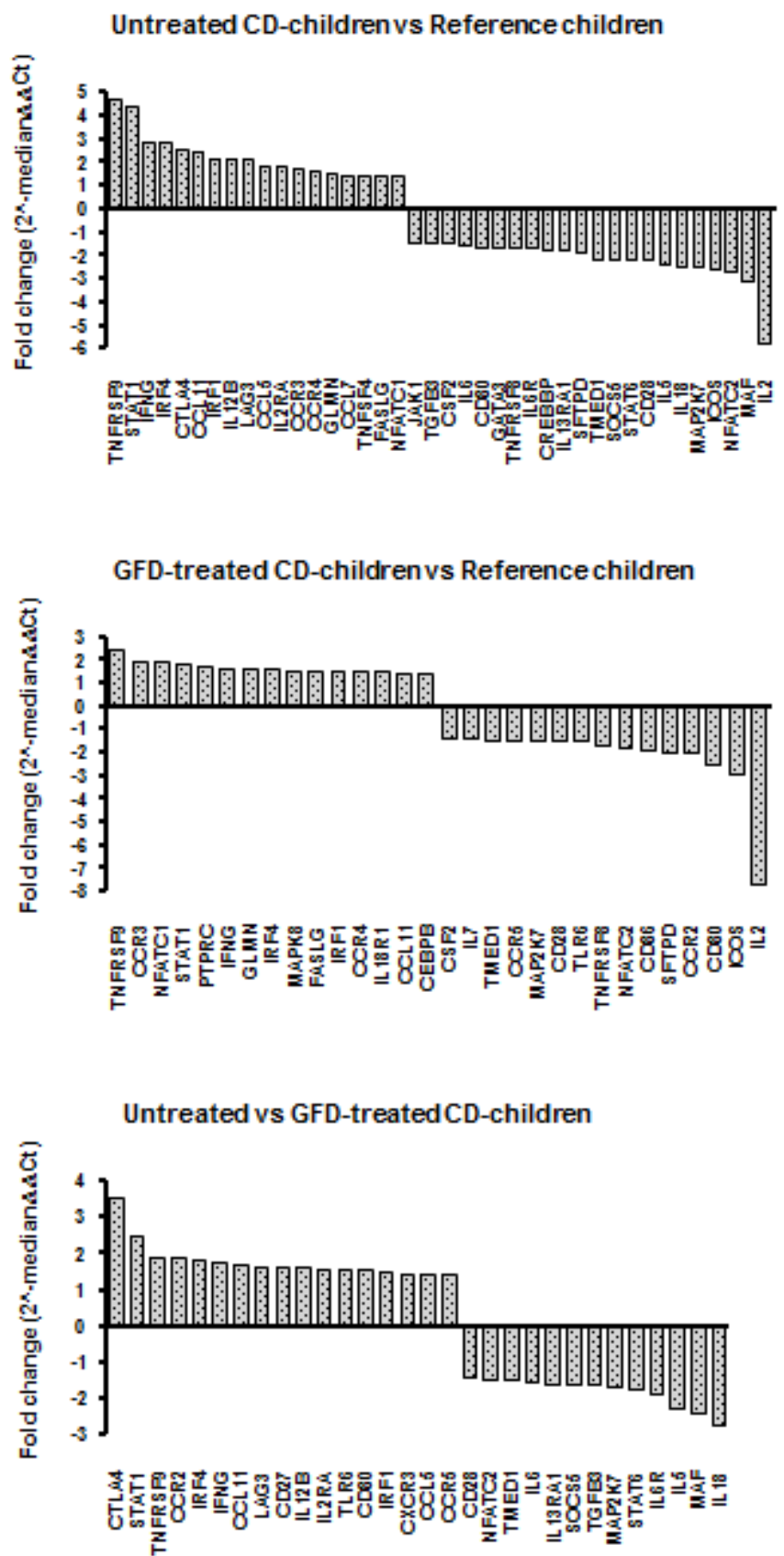

Figure 1.

Median fold changes $\left(2^{\wedge}-\Delta \Delta\right.$ Ct values) of Th1-Th2-Th3 associated gene expression levels in small intestinal biopsies from untreated and gluten-free diet (GFD)-treated children with celiac disease (CD) and reference children. Cut off: $-1.4>x>1.4$. 
Fig. 2

Peripheral gene expression
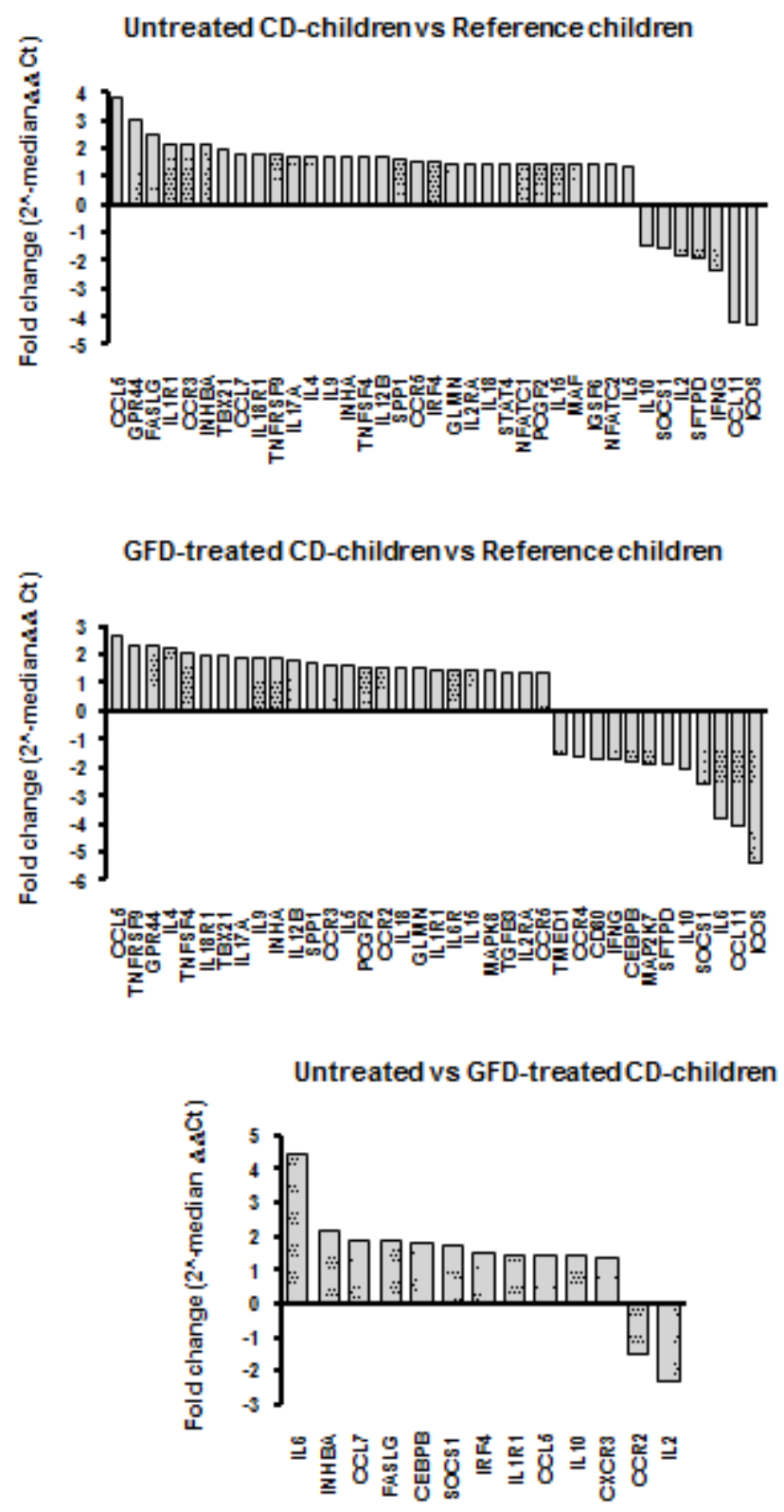

Figure 2.

Median fold changes $\left(2^{\wedge}-\Delta \Delta\right.$ Ct values) of Th1-Th2-Th3 associated gene expression levels in PBMC from untreated and gluten-free diet (GFD)-treated children with celiac diseas (CD) and reference children. Cut off: $-1.4>x>1.4$. 
Fig. 3a)

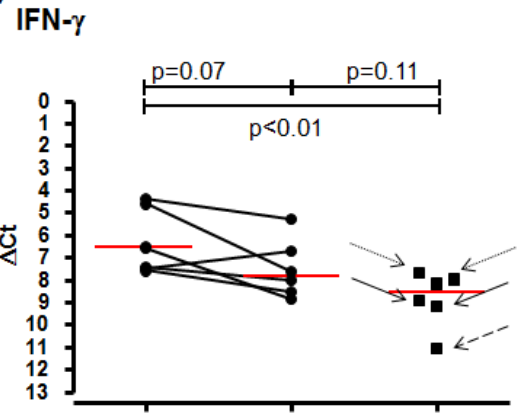

CD-Biopsy 1 CD-Biopsy 2 Reference

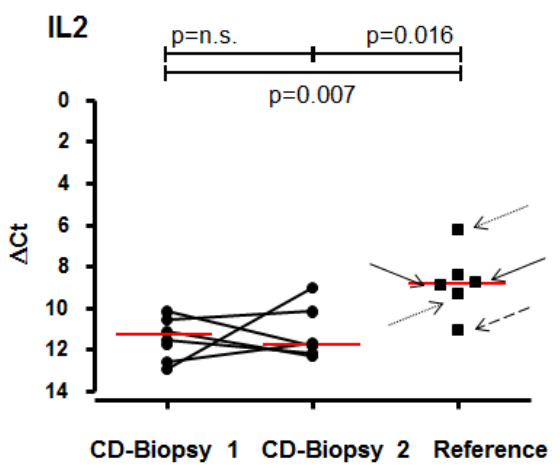

Fig. 3b)

IL13RA1

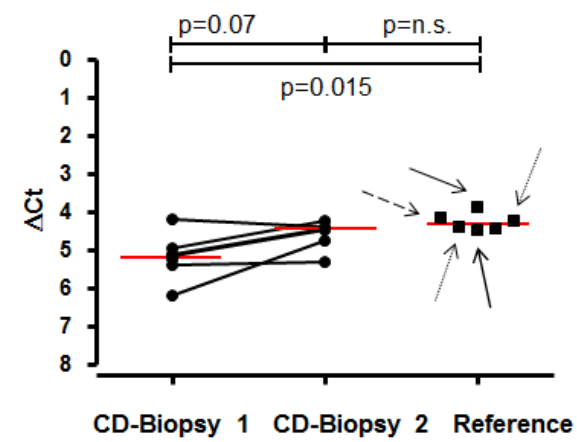

TGF $\beta 3$

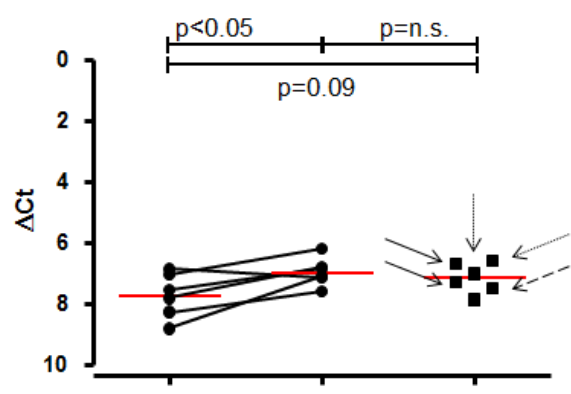

CD-Biopsy 1 CD-Biopsy 2 Reference
STAT1

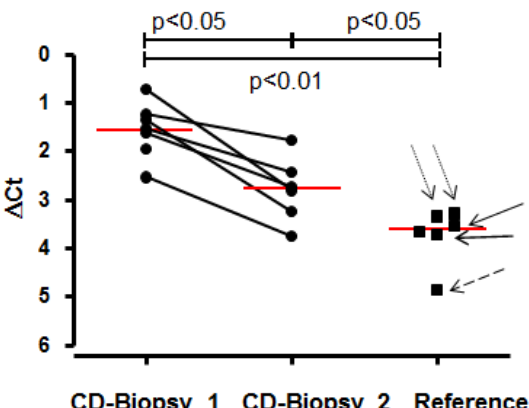

CD80

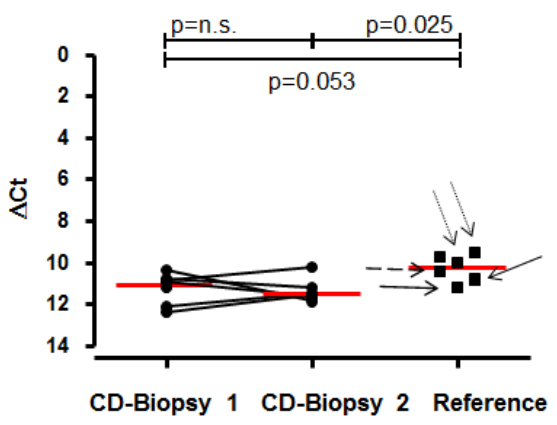

STAT6

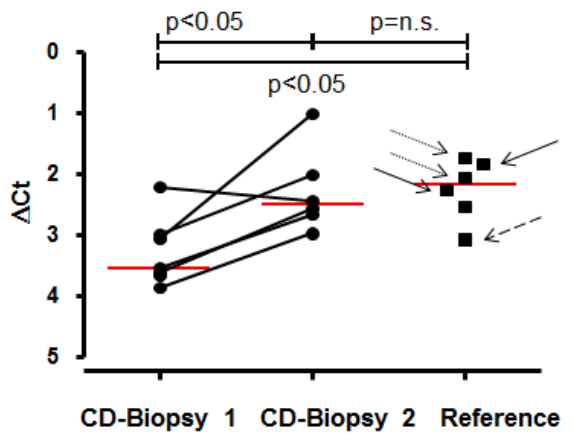

IL18

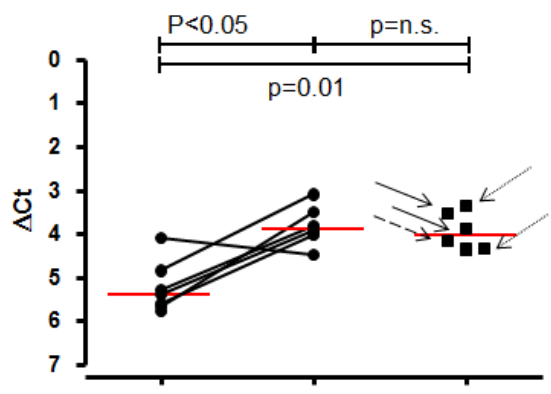

CD-Biopsy 1 CD-Biopsy 2 Reference 
Fig. 3c)
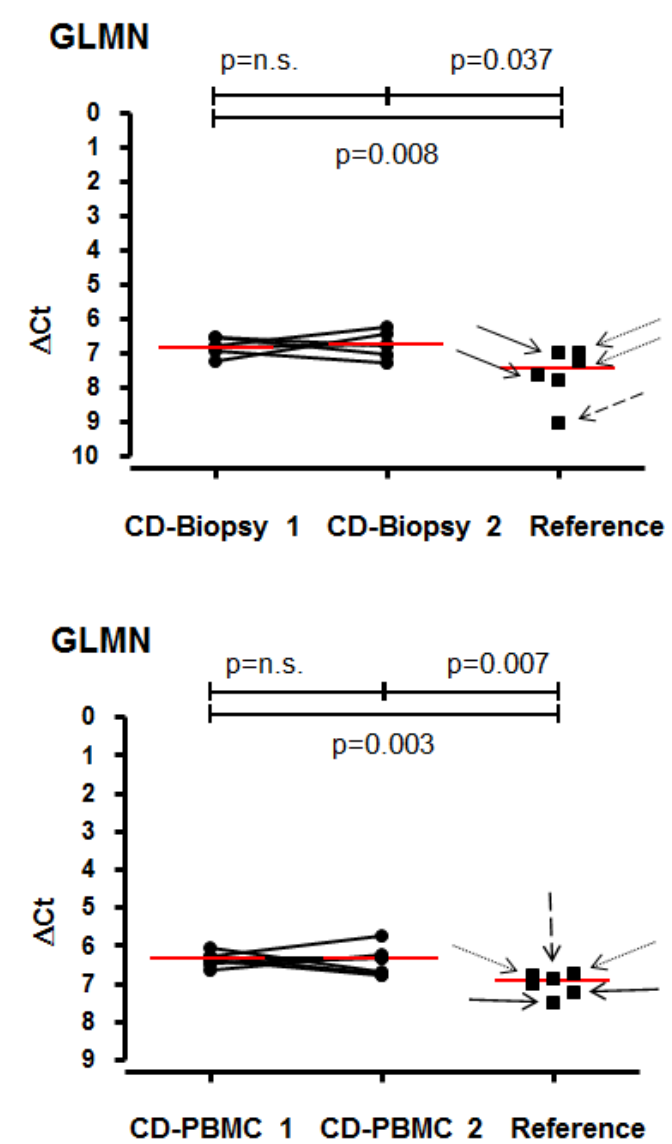

Figure 3.

Scatter plots and median $\Delta$ Ct-values of Th1, Th2 and Th3 associated gene expression in small intestinal biopsies (a, b, c) and PBMC (c) from untreated, gluten-free diet (GFD)treated celiac disease $(C D)$ children and reference children. Mann-Whitney $U$ test $(M-W)$ and Wilcoxon signed ranks test $(\mathrm{Wx})$ was used for comparison of the gene expression profiles between the groups. $\mathrm{P}$-values $<0.05$ were considered significant and $\mathrm{p}$-values $<0.10$ were considered as trends. The arrows indicate reference children with $\lg \mathrm{A}$ deficiency (dotted line), transglutaminase antibody (TGA)-positive reference children who later developed CD (filled line) or remained healthy (broken line), respectively.

a) Expression of IFNy, STAT1, IL2 and CD80 in biopises.

b) Expression of IL13RA1, STAT6, TGFb3 and IL18 in biopsies.

c) Expression of GLMN in biopsies and PBMC. 
Fig. 4

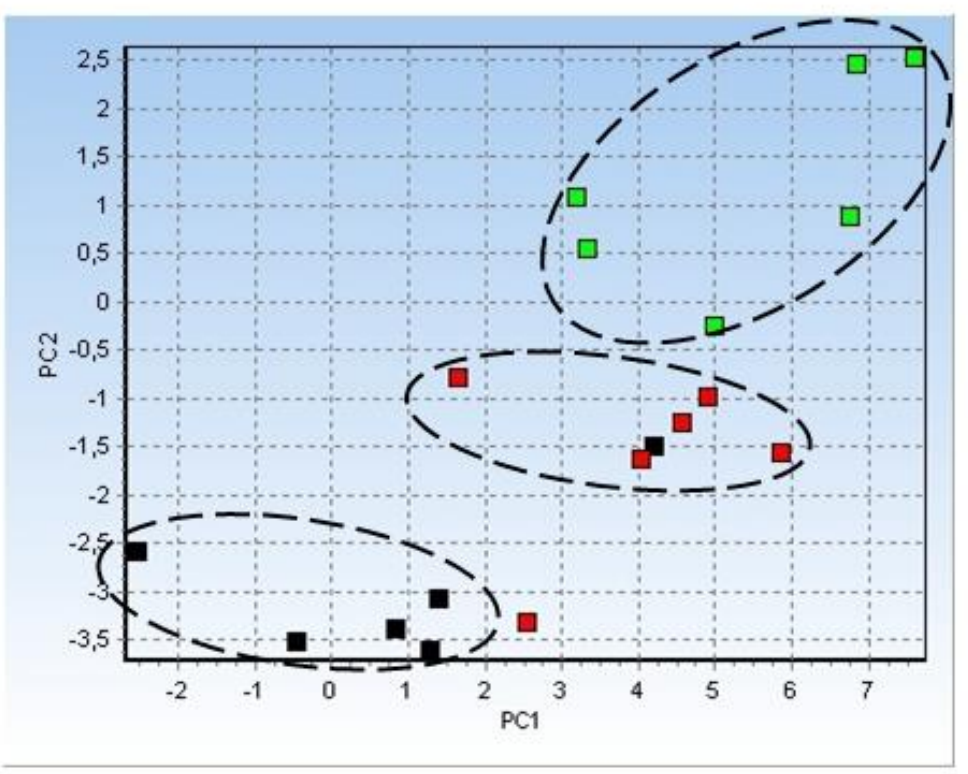

- CD-Bl $=$ Biopsy untreated CD

CD-B2 = Biopsy GFD-treated CD

Ref $(B)=$ Biopsy references

\begin{tabular}{|l|l|}
\hline \multicolumn{2}{|l|}{ Genes included in the PCA: } \\
\hline CD80 & IL6R \\
\hline CREBBP & IRF1 \\
\hline CTLA4 & IRF4 \\
\hline GLMN & JAK1 \\
\hline IFNG & MAF \\
\hline IL13RA1 & MAPK8 \\
\hline IL18 & STAT1 \\
\hline IL2 & STAT6 \\
\hline IL4R & TGFB3 \\
\hline IL5 & TNFRSF9 \\
\hline
\end{tabular}

Figure 4.

Principal component analysis (PCA) visualisation (score plot) of gene expression data from intestinal biopsies. Based on the 20 genes with a fold change of $-1.4>x>1.4$ and $p<$ 0.05 between the study groups; untreated-celiac disease (CD), gluten-free diet (GFD)treated-CD and references (CD-B1, CD-B2 and Ref (B), respectively). 
Fig. 5

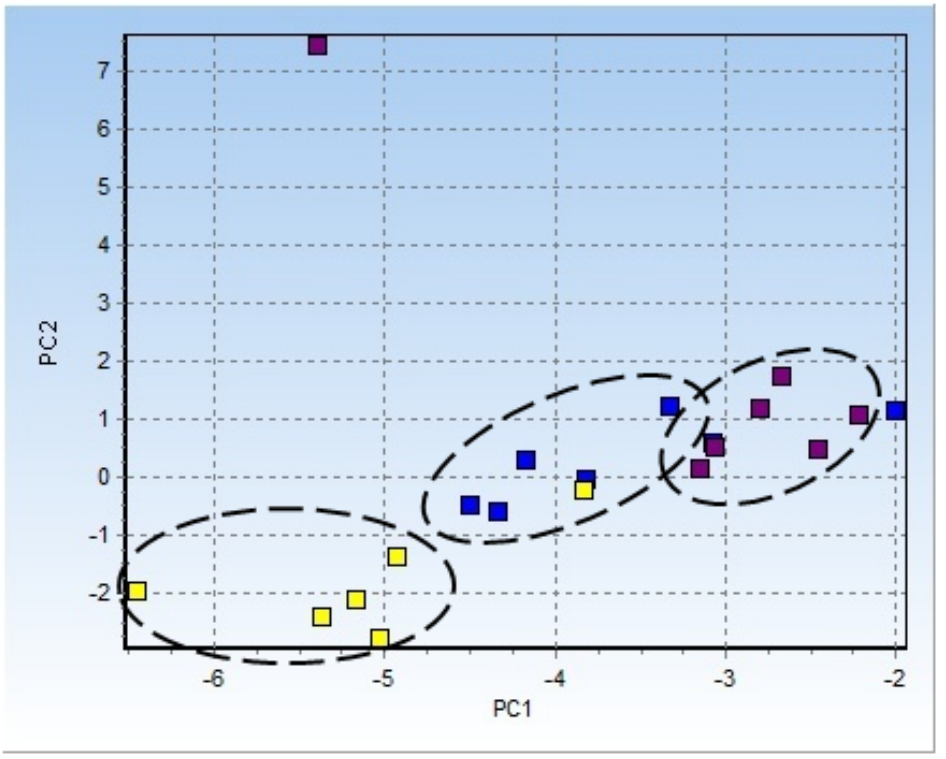

- CD-PI $=$ PBMC untreated CD

CD-P2 = PBMC GFD-treated CD

(1) $\operatorname{Ref}(\mathbf{P})=$ PBMC references

\begin{tabular}{|l|l|}
\hline \multicolumn{2}{|l|}{ Genes included in the PCA: } \\
\hline CCL5 & MAF \\
\hline FASLG & MAPK8 \\
\hline GLMN & SFTPD \\
\hline GPR44 & SOCS1 \\
\hline ICOS & SOCS2 \\
\hline IL15 & TBX21 \\
\hline IL18 & TMED1 \\
\hline IL18R1 & TNFRSF9 \\
\hline IL6 & \\
\hline
\end{tabular}

Figure 5.

Principal component analysis (PCA) visualisation (score plot) of gene expression data from peripheral blood mononuclear cells (PBMC). Based on the 17 genes with a fold change of $-1.4>x>1.4$ and $p<0.05$ between; the study groups; untreated-celiac disease (CD), gluten free diet (GFD)-treated-CD and references (CD-P1, CD-P2 and Ref (P), respectively). 
Table 1 Detailed information about the study population.

\begin{tabular}{|c|c|c|c|c|c|c|c|c|}
\hline & $\begin{array}{c}\text { Age } \\
\text { (years) } \\
\text { Biopsy } 1\end{array}$ & TGA & Biopsy result & Comment & $\begin{array}{c}\text { Age } \\
\text { (years) } \\
\text { Biopsy } 2\end{array}$ & TGA & Biopsy result & Comment \\
\hline CD 1 & 10 & 97 & Marsh $3 b$ & $C D$, Heredity for allergy (AGA neg) & 11 & 6 & Marsh 0 & $\begin{array}{l}\text { Normalisation (slightly } \\
\text { elevated TGA) }\end{array}$ \\
\hline CD 2 & 10 & $>100$ & Marsh 3c & $\begin{array}{c}\text { CD, T1D (for } 4 \text { months), Heredity for } \\
\text { CD and Ulcerous colitis }\end{array}$ & 11 & $<4$ & Marsh 0 & Normalisation \\
\hline CD 3 & 6 & $>100$ & Marsh 3b & CD (slightly elevated AGA) & 7 & $<4$ & Marsh 0 & Normalisation \\
\hline CD 4 & 13 & 10 & Marsh 1 & CD, Heredity for CD & 14 & $<4$ & Marsh 0 & Normalisation \\
\hline CD 5 & 2 & 100 & Marsh 3c & CD (AGA pos) & 3 & $<4$ & Marsh 2 & Improvement \\
\hline CD 6 & 9 & $>100$ & Marsh 3a & CD, T1D (for 4 years) & 10 & $<4$ & Marsh 0 & $\begin{array}{c}\text { Normalisation (AGA } \\
\text { neg) }\end{array}$ \\
\hline CD 7 & 5 & $>100$ & Marsh 3c & CD, Heredity for CD & 6 & $<4$ & Marsh 3a & Improvement \\
\hline Ref 1 & 1 & $<4$ & Marsh 0 & $\begin{array}{c}\text { Non-CD, IgA deficiency inadequate } \\
\text { growth (EMA neg) }\end{array}$ & - & & & \\
\hline Ref 2 & 11 & $<4$ & Marsh 0 & $\begin{array}{l}\text { Non-CD, lgA deficiency, inadequate } \\
\text { growth, Heredity for Ulcerous colitis, } \\
\text { lactose inconvenience (AGA neg, } \\
\text { EMA neg) }\end{array}$ & - & & & \\
\hline Ref 3 & 11 & 9 & Marsh 0 & Potential-CD, Heredity for CD & $\begin{array}{l}\text { New } \\
\text { Biopsy 1, } \\
\text { age 13 } \\
\text { years }\end{array}$ & 10 & Marsh3A & $C D$ \\
\hline Ref 4 & 2 & $<4$ & Marsh 0 & $\begin{array}{l}\text { Non-CD, Down's syndrome (AGA } \\
\text { pos, EMA neg) }\end{array}$ & - & & & \\
\hline Ref 5 & 8 & 11 & Marsh 0 & Potential-CD, Heredity for CD & $\begin{array}{l}\text { New } \\
\text { Biopsy 1, } \\
\text { age } 10 \\
\text { years }\end{array}$ & 36 & Marsh $3 b$ & $C D$ \\
\hline Ref 6 & 3 & 8 & Marsh 0 & $\begin{array}{l}\text { Potential-CD, Heredity for CD, } \\
\text { inadequate growth (AGA neg) }\end{array}$ & - & & & \\
\hline
\end{tabular}

Abbreviations: $C D=$ celiac disease children, Ref=reference children, $T G A=$ transglutaminase antibodies, $A G A=a n t i g l i a d i n ~ a n t i b o d i e s$, $E M A=e n d o m y c i u m$ antibodies, T1D=type 1 diabetes. 
Supplementary table 1. The 84 genes studied in biopsies and peripheral blood mononuclear cells (PBMC) from the study subjects.

\begin{tabular}{|c|c|c|c|c|c|}
\hline \multirow{2}{*}{$\begin{array}{l}\text { Biopsies } \\
\begin{array}{l}\text { Gene } \\
\text { abbreviation }\end{array}\end{array}$} & \multirow[b]{2}{*}{ Description } & \multicolumn{2}{|c|}{ Gene expression in Biopsies } & \multicolumn{2}{|c|}{ Gene expression in PBMC } \\
\hline & & $\begin{array}{l}\text { Pos }(\mathrm{Ct}<35) / \\
\text { Total } \\
\text { responders }\end{array}$ & $\begin{array}{l}\text { Analysed / } \\
\text { Not analysed }\end{array}$ & $\begin{array}{l}\text { Pos }(\mathrm{Ct}<35) / \\
\text { Total } \\
\text { responders }\end{array}$ & $\begin{array}{l}\text { Analysed / } \\
\text { Not analysed }\end{array}$ \\
\hline IL17A & Interleukin 17A & $5 / 18$ & NA & $1 / 20$ & NA \\
\hline CCL11 & Chemokine (C-C motif) ligand 11 & $18 / 18$ & A & $10 / 20$ & A \\
\hline CCL5 & Chemokine (C-C motif) ligand 5 & $18 / 18$ & $\mathbf{A}$ & $20 / 20$ & A \\
\hline CCL7 & Chemokine (C-C motif) ligand 7 & $2 / 18$ & NA & $8 / 20$ & NA \\
\hline CCR2 & Chemokine (C-C motif) receptor 2 & $17 / 18$ & A & $20 / 20$ & A \\
\hline CCR3 & Chemokine (C-C motif) receptor 3 & $14 / 18$ & $\mathbf{A}$ & $19 / 20$ & $\mathbf{A}$ \\
\hline CCR4 & Chemokine (C-C motif) receptor 4 & $11 / 18$ & NA & $20 / 20$ & A \\
\hline CCR5 & Chemokine (C-C motif) receptor 5 & $18 / 18$ & $\mathbf{A}$ & $20 / 20$ & $\mathbf{A}$ \\
\hline CD28 & CD28 molecule & $8 / 18$ & NA & $19 / 20$ & $\mathbf{A}$ \\
\hline CD4 & CD4 molecule & $18 / 18$ & A & $20 / 20$ & A \\
\hline CD40LG & $\begin{array}{l}\text { CD40 ligand (TNF superfamily, member } \\
5, \text { hyper-IgM syndrome) }\end{array}$ & $18 / 18$ & A & $20 / 20$ & A \\
\hline IL23A & Interleukin 23, alpha subunit p19 & $18 / 18$ & A & $20 / 20$ & $\mathbf{A}$ \\
\hline CD80 & CD80 molecule & $17 / 18$ & $\mathbf{A}$ & $19 / 20$ & A \\
\hline CD86 & CD86 molecule & $18 / 18$ & A & $20 / 20$ & A \\
\hline CEBPB & $\begin{array}{l}\text { CCAAT/enhancer binding protein } \\
\text { (C/EBP), beta }\end{array}$ & $18 / 18$ & $\mathbf{A}$ & $20 / 20$ & A \\
\hline CREBBP & $\begin{array}{l}\text { CREB binding protein (Rubinstein-Taybi } \\
\text { syndrome) }\end{array}$ & $18 / 18$ & A & $20 / 20$ & A \\
\hline CSF2 & $\begin{array}{l}\text { Colony stimulating factor } 2 \\
\text { (granulocyte-macrophage) }\end{array}$ & $15 / 18$ & NA & $15 / 20$ & $\mathbf{A}$ \\
\hline CTLA4 & $\begin{array}{l}\text { Cytotoxic T-lymphocyte-associated } \\
\text { protein } 4\end{array}$ & $18 / 18$ & $\mathbf{A}$ & $20 / 20$ & $\mathbf{A}$ \\
\hline CXCR3 & Chemokine (C-X-C motif) receptor 3 & $18 / 18$ & A & $20 / 20$ & $\mathbf{A}$ \\
\hline FASLG & Fas ligand (TNF superfamily, member 6 ) & $18 / 18$ & A & $20 / 20$ & A \\
\hline GATA3 & GATA binding protein 3 & $17 / 18$ & A & $20 / 20$ & $\mathbf{A}$ \\
\hline GFI1 & $\begin{array}{l}\text { Growth factor independent } 1 \\
\text { transcription repressor }\end{array}$ & $18 / 18$ & A & $20 / 20$ & A \\
\hline GLMN & Glomulin, FKBP associated protein & $18 / 18$ & A & $20 / 20$ & $\mathbf{A}$ \\
\hline GPR44 & G protein-coupled receptor 44 & $17 / 18$ & A & $19 / 20$ & A \\
\hline HAVCR2 & Hepatitis A virus cellular receptor 2 & $18 / 18$ & A & $20 / 20$ & A \\
\hline ICOS & Inducible T-cell co-stimulator & $15 / 18$ & A & $20 / 20$ & $\mathbf{A}$ \\
\hline IFNG & Interferon, gamma & $18 / 18$ & A & $20 / 20$ & $\mathbf{A}$ \\
\hline IGSF6 & Immunoglobulin superfamily, member 6 & $18 / 18$ & A & $20 / 20$ & A \\
\hline IL10 & Interleukin 10 & $4 / 18$ & NA & $17 / 20$ & $\mathbf{A}$ \\
\hline IL12B & $\begin{array}{l}\text { Interleukin 12B (natural killer cell } \\
\text { stimulatory factor } 2 \text {, cytotoxic } \\
\text { lymphocyte maturation factor } 2, \text { p40) }\end{array}$ & 9/18 & NA & $7 / 20$ & NA \\
\hline IL12RB2 & Interleukin 12 receptor, beta 2 & $1 / 18$ & NA & $10 / 20$ & NA \\
\hline IL13 & Interleukin 13 & $11 / 18$ & NA & $20 / 20$ & A \\
\hline IL13RA1 & Interleukin 13 receptor, alpha 1 & $18 / 18$ & A & $20 / 20$ & A \\
\hline IL15 & Interleukin 15 & $18 / 18$ & A & $20 / 20$ & A \\
\hline IL18 & $\begin{array}{l}\text { Interleukin } 18 \text { (interferon-gamma- } \\
\text { inducing factor) }\end{array}$ & $18 / 18$ & $\mathbf{A}$ & $20 / 20$ & $\mathbf{A}$ \\
\hline IL18R1 & Interleukin 18 receptor 1 & $18 / 18$ & A & $20 / 20$ & $\mathbf{A}$ \\
\hline IL1R1 & Interleukin 1 receptor, type I & $18 / 18$ & A & $20 / 20$ & A \\
\hline IL1R2 & Interleukin 1 receptor, type II & $17 / 18$ & A & $20 / 20$ & $\mathbf{A}$ \\
\hline IL2 & Interleukin 2 & $17 / 18$ & A & $19 / 20$ & $\mathbf{A}$ \\
\hline IL2RA & Interleukin 2 receptor, alpha & $18 / 18$ & A & $20 / 20$ & A \\
\hline IL4 & Interleukin 4 & 4/18 & NA & $2 / 20$ & NA \\
\hline IL4R & Interleukin 4 receptor & $18 / 18$ & A & $20 / 20$ & $\mathbf{A}$ \\
\hline IL5 & $\begin{array}{l}\text { Interleukin } 5 \text { (colony-stimulating factor, } \\
\text { eosinophil) }\end{array}$ & $15 / 18$ & $\mathbf{A}$ & $20 / 20$ & $\mathbf{A}$ \\
\hline IL6 & Interleukin 6 (interferon, beta 2) & $16 / 18$ & A & $20 / 20$ & A \\
\hline IL6R & Interleukin 6 receptor & $18 / 18$ & A & $20 / 20$ & A \\
\hline IL7 & Interleukin 7 & $18 / 18$ & A & $20 / 20$ & A \\
\hline
\end{tabular}




\begin{tabular}{|c|c|c|c|c|c|}
\hline IL9 & Interleukin 9 & 3/18 & NA & $0 / 20$ & NA \\
\hline INHA & Inhibin, alpha & $6 / 18$ & NA & $1 / 20$ & NA \\
\hline INHBA & Inhibin, beta A & $18 / 18$ & A & $20 / 20$ & A \\
\hline IRF1 & Interferon regulatory factor 1 & $18 / 18$ & $\mathbf{A}$ & $20 / 20$ & $\mathbf{A}$ \\
\hline IRF4 & Interferon regulatory factor 4 & $18 / 18$ & A & $20 / 20$ & $\mathbf{A}$ \\
\hline JAK1 & $\begin{array}{l}\text { Janus kinase } 1 \text { (a protein tyrosine } \\
\text { kinase) }\end{array}$ & $18 / 18$ & A & 20/20 & A \\
\hline JAK2 & $\begin{array}{l}\text { Janus kinase } 2 \text { (a protein tyrosine } \\
\text { kinase) }\end{array}$ & 18/18 & A & $20 / 20$ & A \\
\hline LAG3 & Lymphocyte-activation gene 3 & $18 / 18$ & A & $20 / 20$ & $\mathbf{A}$ \\
\hline LAT & Linker for activation of $\mathrm{T}$ cells & $18 / 18$ & $\mathbf{A}$ & $20 / 20$ & $\mathbf{A}$ \\
\hline MAF & $\begin{array}{l}\text { V-maf musculoaponeurotic } \\
\text { fibrosarcoma oncogene homolog } \\
\text { (avian) }\end{array}$ & $18 / 18$ & A & $19 / 20$ & A \\
\hline MAP2K7 & $\begin{array}{l}\text { Mitogen-activated protein kinase kinase } \\
7\end{array}$ & 18/18 & A & $20 / 20$ & A \\
\hline MAPK8 & Mitogen-activated protein kinase 8 & $18 / 18$ & A & $20 / 20$ & $\mathbf{A}$ \\
\hline NFATC1 & $\begin{array}{l}\text { Nuclear factor of activated T-cells, } \\
\text { cytoplasmic, calcineurin-dependent } 1\end{array}$ & $18 / 18$ & A & $20 / 20$ & A \\
\hline NFATC2 & $\begin{array}{l}\text { Nuclear factor of activated T-cells, } \\
\text { cytoplasmic, calcineurin-dependent } 2\end{array}$ & 18/18 & A & $20 / 20$ & A \\
\hline NFATC2IP & $\begin{array}{l}\text { Nuclear factor of activated T-cells, } \\
\text { cytoplasmic, calcineurin-dependent } 2 \\
\text { interacting protein }\end{array}$ & 18/18 & A & $20 / 20$ & $\mathbf{A}$ \\
\hline PCGF2 & Polycomb group ring finger 2 & $18 / 18$ & A & $19 / 20$ & $\mathbf{A}$ \\
\hline PTPRC & $\begin{array}{l}\text { Protein tyrosine phosphatase, receptor } \\
\text { type, C }\end{array}$ & 18/18 & $\mathbf{A}$ & $20 / 20$ & $\mathbf{A}$ \\
\hline SFTPD & $\begin{array}{l}\text { Surfactant, pulmonary-associated } \\
\text { protein D }\end{array}$ & $10 / 18$ & NA & $18 / 20$ & A \\
\hline SOCS1 & Suppressor of cytokine signaling 1 & $18 / 18$ & $\mathbf{A}$ & $20 / 20$ & $\mathbf{A}$ \\
\hline SOCS2 & Suppressor of cytokine signaling 2 & $18 / 18$ & A & $20 / 20$ & $\mathbf{A}$ \\
\hline SOCS5 & Suppressor of cytokine signaling 5 & $18 / 18$ & A & $20 / 20$ & A \\
\hline SPP1 & $\begin{array}{l}\text { Secreted phosphoprotein } 1 \\
\text { (osteopontin, bone sialoprotein I, early } \\
\text { T-lymphocyte activation 1) }\end{array}$ & 18/18 & $\bar{A}$ & $3 / 20$ & NA \\
\hline STAT1 & $\begin{array}{l}\text { Signal transducer and activator of } \\
\text { transcription } 1,91 \mathrm{kDa}\end{array}$ & $18 / 18$ & $\bar{A}$ & $20 / 20$ & $\mathbf{A}$ \\
\hline STAT4 & $\begin{array}{l}\text { Signal transducer and activator of } \\
\text { transcription } 4\end{array}$ & 18/18 & $\mathbf{A}$ & $20 / 20$ & $\mathbf{A}$ \\
\hline STAT6 & $\begin{array}{l}\text { Signal transducer and activator of } \\
\text { transcription } 6 \text {, interleukin-4 induced }\end{array}$ & $18 / 18$ & $\bar{A}$ & $20 / 20$ & $\mathbf{A}$ \\
\hline TBX21 & T-box 21 & $18 / 18$ & A & $20 / 20$ & A \\
\hline TFCP2 & Transcription factor CP2 & $18 / 18$ & $\mathbf{A}$ & $20 / 20$ & $\mathbf{A}$ \\
\hline TGFB3 & Transforming growth factor, beta 3 & $18 / 18$ & A & $20 / 20$ & $\mathbf{A}$ \\
\hline TLR4 & Toll-like receptor 4 & $18 / 18$ & A & $20 / 20$ & A \\
\hline TLR6 & Toll-like receptor 6 & $18 / 18$ & A & $20 / 20$ & A \\
\hline TMED1 & $\begin{array}{l}\text { Transmembrane emp24 protein } \\
\text { transport domain containing } 1\end{array}$ & 18/18 & A & $20 / 20$ & $\mathbf{A}$ \\
\hline TNF & $\begin{array}{l}\text { Tumor necrosis factor (TNF } \\
\text { superfamily, member 2) }\end{array}$ & $18 / 18$ & A & $20 / 20$ & A \\
\hline CD27 & CD27 molecule & $18 / 18$ & A & $20 / 20$ & $\mathbf{A}$ \\
\hline TNFRSF8 & $\begin{array}{l}\text { Tumor necrosis factor receptor } \\
\text { superfamily, member } 8\end{array}$ & $17 / 18$ & A & $20 / 20$ & A \\
\hline TNFRSF9 & $\begin{array}{l}\text { Tumor necrosis factor receptor } \\
\text { superfamily, member } 9\end{array}$ & $18 / 18$ & A & $20 / 20$ & A \\
\hline TNFSF4 & $\begin{array}{l}\text { Tumor necrosis factor (ligand) } \\
\text { superfamily, member } 4 \text { (tax- } \\
\text { transcriptionally activated glycoprotein } \\
1,34 \mathrm{kDa})\end{array}$ & $0 / 18$ & NA & $5 / 20$ & NA \\
\hline TYK2 & Tyrosine kinase 2 & $18 / 18$ & A & $20 / 20$ & $\mathbf{A}$ \\
\hline YY1 & YY1 transcription factor & $18 / 18$ & $\mathbf{A}$ & $20 / 20$ & $\mathbf{A}$ \\
\hline
\end{tabular}


Supplemantary Table 2. Median $\Delta \mathrm{Ct}$ values of Th1-Th2-Th3 associated gene expression levels in small intestinal biopsies (Suppl. Table 2a) and peripheral blood mononuclear cells (PBMC) (Suppl. Table 2b) from children with celiac disease (CD) before and after gluten-free diet (GFD) treatment. Mann-Whitney U test (M-W) and Wilcoxon signed ranks test (Wx) was used for comparison of the gene expression profiles between the groups. P-values $<0.05$ were considered significant and $p$-values $<0.10$ were considered as trends. The genes marked in bold show differences between the groups in both $\Delta$ Ct-values and median fold change $\left(2^{\wedge}\right.$ median $\Delta \Delta \mathrm{Ct}$ ) with the cut off levels: $-1.4 \geq \mathrm{x} \geq 1.4$.

a) Gene expression in small intestinal biopsies from untreated (CD-B1), GFD-treated (CD-B2) children with CD and reference children (Ref-B).

\begin{tabular}{|c|c|c|c|c|c|c|c|}
\hline Biopsies & & CD-B1 & CD-B2 & $\operatorname{Ref}(B)$ & $\begin{array}{c}C D- \\
B 1 \text { vs } \\
B 2\end{array}$ & $\begin{array}{c}C D- \\
\text { B1 vs } \\
\text { Ref } \\
\text { (B) }\end{array}$ & $\begin{array}{c}\text { CD- } \\
\text { B2 vs } \\
\text { Ref } \\
\text { (B) }\end{array}$ \\
\hline $\begin{array}{l}\text { Gene } \\
\text { abbreviation }\end{array}$ & Description & $\begin{array}{c}\text { median } \\
\Delta \mathrm{Ct}\end{array}$ & $\begin{array}{c}\text { median } \\
\Delta \mathrm{Ct}\end{array}$ & $\begin{array}{l}\text { median } \\
\Delta \mathrm{Ct}\end{array}$ & $W x$ & $M-W$ & $M-W$ \\
\hline CCL11 & Chemokine (C-C motif) ligand 11 & 4,68 & 6,35 & 6,84 & n.s. & n.s. & n.s. \\
\hline CCL5 & Chemokine (C-C motif) ligand 5 & 3,02 & 3,37 & 3,74 & n.s. & n.s. & n.s. \\
\hline CCR2 & Chemokine (C-C motif) receptor 2 & 9,79 & 10,96 & 9,93 & n.s. & n.s. & 0.05 \\
\hline CCR3 & Chemokine (C-C motif) receptor 3 & 11,70 & 11,45 & 12,43 & n.s. & n.s. & n.s. \\
\hline CCR5 & Chemokine (C-C motif) receptor 5 & 6,95 & 7,28 & 6,71 & n.s. & n.s. & n.s. \\
\hline CD80 & CD80 molecule & 10,91 & 11,53 & 10,22 & n.s. & 0.05 & 0.02 \\
\hline CD86 & CD86 molecule & 10,03 & 10,09 & 9,17 & n.s. & n.s. & 0.08 \\
\hline CEBPB & CCAAT/enhancer binding protein (C/EBP), beta & 5,01 & 4,87 & 5,35 & n.s. & n.s. & n.s. \\
\hline CREBBP & CREB binding protein (Rubinstein-Taybi syndrome) & 7,02 & 6,57 & 6,21 & n.s. & 0.01 & 0.06 \\
\hline CTLA4 & Cytotoxic T-lymphocyte-associated protein 4 & 9,08 & 10,91 & 10,42 & 0.03 & n.s. & n.s. \\
\hline CXCR3 & Chemokine (C-X-C motif) receptor 3 & 9,12 & 9,60 & 9,24 & n.s. & n.s. & n.s. \\
\hline FASLG & Fas ligand (TNF superfamily, member 6) & 7,72 & 7,65 & 8,23 & n.s. & n.s. & n.s. \\
\hline GATA3 & GATA binding protein 3 & 10,56 & 10,68 & 10,37 & n.s. & n.s. & n.s. \\
\hline GLMN & Glomulin, FKBP associated protein & 6,87 & 6,80 & 7,49 & n.s. & 0.008 & 0.04 \\
\hline ICOS & Inducible T-cell co-stimulator & 12,17 & 12,26 & 10,68 & n.s. & n.s. & 0.05 \\
\hline IFNG & Interferon, gamma & 6,61 & 7,83 & 8,56 & 0.07 & 0.003 & n.s. \\
\hline IL13RA1 & Interleukin 13 receptor, alpha 1 & 5,18 & 4,47 & 4,35 & 0.07 & 0.01 & n.s. \\
\hline IL18 & Interleukin 18 (interferon-gamma-inducing factor) & 5,39 & 3,88 & 4,03 & 0.05 & 0.01 & n.s. \\
\hline IL18R1 & Interleukin 18 receptor 1 & 7,41 & 6,75 & 7,31 & n.s. & n.s. & n.s. \\
\hline IL2 & Interleukin 2 & 11,56 & 11,78 & 8,84 & n.s. & 0.007 & 0.02 \\
\hline IL2RA & Interleukin 2 receptor, alpha & 8,39 & 8,70 & 8,93 & n.s. & n.s. & n.s. \\
\hline IL4R & Interleukin 4 receptor & 4,06 & 4,04 & 3,54 & n.s. & 0.02 & n.s. \\
\hline IL5 & Interleukin 5 (colony-stimulating factor, eosinophil) & 11,57 & 10,51 & 10,46 & n.s. & 0.02 & n.s. \\
\hline IL6 & Interleukin 6 (interferon, beta 2) & 11,56 & 11,24 & 11,30 & n.s. & n.s. & n.s. \\
\hline IL6R & Interleukin 6 receptor & 6,69 & 5,77 & 5,90 & 0.03 & n.s. & n.s. \\
\hline IL7 & Interleukin 7 & 5,38 & 5,96 & 5,44 & n.s. & n.s. & n.s. \\
\hline IRF1 & Interferon regulatory factor 1 & 3,35 & 3,81 & 4,38 & n.s. & 0.004 & 0.06 \\
\hline IRF4 & Interferon regulatory factor 4 & 4,69 & 5,72 & 6,39 & 0.03 & 0.01 & n.s. \\
\hline JAK1 & Janus kinase 1 (a protein tyrosine kinase) & 3,62 & 3,20 & 2,96 & n.s. & 0.01 & n.s. \\
\hline LAG3 & Lymphocyte-activation gene 3 & 6,76 & 7,35 & 7,74 & n.s. & n.s. & n.s. \\
\hline LAT & Linker for activation of T cells & 6,60 & 6,35 & 6,38 & n.s. & n.s. & n.s. \\
\hline MAF & $\begin{array}{l}\text { V-maf musculoaponeurotic fibrosarcoma oncogene } \\
\text { homolog (avian) }\end{array}$ & 4,37 & 2,87 & 2,48 & 0.07 & 0.03 & n.s. \\
\hline MAP2K7 & Mitogen-activated protein kinase kinase 7 & 8,72 & 7,92 & 7,32 & n.s. & 0.09 & n.s. \\
\hline MAPK8 & Mitogen-activated protein kinase 8 & 5,18 & 4,68 & 5,29 & n.s. & n.s. & 0.03 \\
\hline NFATC1 & $\begin{array}{l}\text { Nuclear factor of activated T-cells, cytoplasmic, } \\
\text { calcineurin-dependent } 1\end{array}$ & 8,16 & 7,66 & 8,57 & n.s. & n.s. & n.s. \\
\hline NFATC2 & $\begin{array}{l}\text { Nuclear factor of activated T-cells, cytoplasmic, } \\
\text { calcineurin-dependent } 2\end{array}$ & 10,09 & 9,36 & 8,46 & n.s. & n.s. & n.s. \\
\hline PCGF2 & Polycomb group ring finger 2 & 7,00 & 6,93 & 6,65 & n.s. & n.s. & n.s. \\
\hline PTPRC & Protein tyrosine phosphatase, receptor type, C & 3,23 & 2,93 & 3,68 & n.s. & n.s. & n.s. \\
\hline SOCS5 & Suppressor of cytokine signaling 5 & 8,54 & 7,84 & 7,44 & n.s. & n.s. & n.s. \\
\hline STAT1 & $\begin{array}{l}\text { Signal transducer and activator of transcription } 1, \\
91 \mathrm{kDa}\end{array}$ & 1,55 & 2,78 & 3,61 & 0.03 & 0.003 & 0.04 \\
\hline STAT6 & $\begin{array}{l}\text { Signal transducer and activator of transcription } 6 \text {, } \\
\text { interleukin-4 induced }\end{array}$ & 3,54 & 2,51 & 2,17 & 0.05 & 0.02 & n.s. \\
\hline
\end{tabular}




\begin{tabular}{|l|l|c|c|c|c|c|c|}
\hline TGFB3 & Transforming growth factor, beta 3 & 7,84 & 7,00 & 7,18 & $\mathbf{0 . 0 5}$ & 0.09 & n.s. \\
\hline TLR6 & Toll-like receptor 6 & 9,18 & 9,82 & 9,18 & n.s. & n.s. & n.s. \\
\hline TMED1 & $\begin{array}{l}\text { Transmembrane emp24 protein transport domain } \\
\text { containing 1 }\end{array}$ & 7,75 & 7,19 & 6,64 & n.s. & 0.10 & n.s. \\
\hline CD27 & CD27 molecule & 4,24 & 5,13 & 4,80 & n.s. & 0.09 & n.s. \\
\hline TNFRSF8 & $\begin{array}{l}\text { Tumor necrosis factor receptor superfamily, } \\
\text { member 8 }\end{array}$ & 11,72 & 11,82 & 11,00 & n.s. & n.s. & n.s. \\
\hline TNFRSF9 & $\begin{array}{l}\text { Tumor necrosis factor receptor superfamily, } \\
\text { member 9 }\end{array}$ & 8,91 & 9,90 & 11,22 & n.s. & $\mathbf{0 . 0 1}$ & n.s. \\
\hline
\end{tabular}


Supplementary Table 2b) Gene expression in PBMC from untreated (CD-P1), GFD-treated (CD-P2) children with CD and reference children (Ref-P).

\begin{tabular}{|c|c|c|c|c|c|c|c|}
\hline PBMC & & CD-P1 & CD-P2 & $\operatorname{Ref}(P)$ & $\begin{array}{l}C D-P 1 \\
\text { vs } P 2\end{array}$ & $\begin{array}{c}C D-P 1 \\
\text { vs Ref } \\
(P)\end{array}$ & $\begin{array}{c}C D-P 2 \\
\text { vs Ref } \\
(P)\end{array}$ \\
\hline $\begin{array}{l}\text { Gene } \\
\text { abbreviation }\end{array}$ & Description & $\begin{array}{c}\text { median } \\
\Delta \mathrm{Ct}\end{array}$ & $\begin{array}{c}\text { median } \\
\Delta \mathrm{Ct}\end{array}$ & $\begin{array}{c}\text { median } \\
\Delta \mathrm{Ct}\end{array}$ & $W x$ & $M-W$ & $M-W$ \\
\hline CCL5 & Chemokine (C-C motif) ligand 5 & 1,13 & 1,66 & 3,07 & n.s. & 0.02 & 0.04 \\
\hline CCR2 & Chemokine (C-C motif) receptor 2 & 7,69 & 7,12 & 7,74 & 0.09 & n.s. & 0.09 \\
\hline CCR3 & Chemokine (C-C motif) receptor 3 & 10,67 & 11,06 & 11,80 & n.s. & n.s. & 0.09 \\
\hline CCR4 & Chemokine (C-C motif) receptor 4 & 8,16 & 8,56 & 7,91 & n.s. & n.s. & n.s. \\
\hline CCR5 & Chemokine (C-C motif) receptor 5 & 7,32 & 7,49 & 7,98 & n.s. & n.s. & n.s. \\
\hline CD80 & CD80 molecule & 10,96 & 11,30 & 10,58 & n.s. & n.s. & n.s. \\
\hline CEBPB & CCAAT/enhancer binding protein (C/EBP), beta & 2,88 & 3,76 & 2,92 & n.s. & n.s. & n.s. \\
\hline CXCR3 & Chemokine (C-X-C motif) receptor 3 & 7,03 & 7,54 & 7,22 & 0.09 & n.s. & n.s. \\
\hline FASLG & Fas ligand (TNF superfamily, member 6 ) & 8,09 & 9,04 & 9,45 & 0.02 & 0.004 & n.s. \\
\hline GLMN & Glomulin, FKBP associated protein & 6,33 & 6,34 & 6,94 & n.s. & 0.003 & 0.007 \\
\hline GPR44 & G protein-coupled receptor 44 & 10,66 & 11,06 & 12,29 & n.s. & 0.02 & 0.003 \\
\hline ICOS & Inducible T-cell co-stimulator & 7,63 & 7,96 & 5,53 & 0.06 & 0.01 & 0.01 \\
\hline IFNG & Interferon, gamma & 6,72 & 6,23 & 5,51 & n.s. & n.s. & n.s. \\
\hline IGSF6 & Immunoglobulin superfamily, member 6 & 5,17 & 5,20 & 5,68 & n.s. & 0.09 & 0.06 \\
\hline IL10 & Interleukin 10 & 12,49 & 13,01 & 11,98 & n.s. & n.s. & 0.09 \\
\hline IL15 & Interleukin 15 & 6,53 & 6,53 & 7,06 & n.s. & 0.01 & 0.01 \\
\hline IL18 & Interleukin 18 (interferon-gamma-inducing factor) & 6,78 & 6,73 & 7,34 & n.s. & 0.06 & 0.02 \\
\hline IL18R1 & Interleukin 18 receptor 1 & 6,59 & 6,43 & 7,44 & n.s. & 0.03 & 0.007 \\
\hline IL1R1 & Interleukin 1 receptor, type I & 7,86 & 8,40 & 8,99 & n.s. & n.s. & n.s. \\
\hline IL2 & Interleukin 2 & 12,89 & 11,72 & 12,07 & n.s. & n.s. & n.s. \\
\hline IL2RA & Interleukin 2 receptor, alpha & 7,53 & 7,63 & 8,12 & n.s. & 0.09 & 0.06 \\
\hline IL5 & Interleukin 5 (colony-stimulating factor, eosinophil) & 11,64 & 11,45 & 12,13 & n.s. & n.s. & n.s. \\
\hline IL6 & Interleukin 6 (interferon, beta 2) & 7,08 & 9,24 & 7,34 & 0.06 & n.s. & 0.01 \\
\hline IL6R & Interleukin 6 receptor & 4,82 & 4,46 & 5,00 & n.s. & n.s. & n.s. \\
\hline INHBA & Inhibin, beta A & 9,23 & 10,36 & 10,35 & n.s. & n.s. & n.s. \\
\hline IRF4 & Interferon regulatory factor 4 & 4,05 & 4,69 & 4,67 & 0.09 & n.s. & n.s. \\
\hline MAF & $\begin{array}{l}\text { V-maf musculoaponeurotic fibrosarcoma oncogene } \\
\text { homolog (avian) }\end{array}$ & 5,26 & 5,51 & 5,78 & 0.04 & 0.01 & n.s. \\
\hline MAP2K7 & Mitogen-activated protein kinase kinase 7 & 8,95 & 9,40 & 8,50 & n.s. & n.s. & n.s. \\
\hline MAPK8 & Mitogen-activated protein kinase 8 & 5,75 & 5,63 & 6,15 & n.s. & 0.007 & 0.03 \\
\hline NFATC1 & $\begin{array}{l}\text { Nuclear factor of activated T-cells, cytoplasmic, } \\
\text { calcineurin-dependent } 1\end{array}$ & 4,71 & 4,94 & 5,26 & n.s. & 0.07 & n.s. \\
\hline NFATC2 & $\begin{array}{l}\text { Nuclear factor of activated T-cells, cytoplasmic, } \\
\text { calcineurin-dependent } 2\end{array}$ & 6,84 & 6,95 & 7,35 & n.s. & n.s. & n.s. \\
\hline PCGF2 & Polycomb group ring finger 2 & 12,06 & 11,97 & 12,59 & n.s. & n.s. & n.s. \\
\hline SFTPD & Surfactant, pulmonary-associated protein D & 13,01 & 13,01 & 12,09 & n.s. & 0.02 & n.s. \\
\hline SOCS1 & Suppressor of cytokine signaling 1 & 5,53 & 6,33 & 4,96 & 0.04 & 0.04 & 0.003 \\
\hline SOCS2 & Suppressor of cytokine signaling 2 & 11,42 & 10,93 & 11,29 & n.s. & n.s. & 0.03 \\
\hline STAT4 & Signal transducer and activator of transcription 4 & 4,91 & 5,17 & 5,46 & n.s. & 0.05 & 0.06 \\
\hline TBX21 & T-box 21 & 4,65 & 4,68 & 5,65 & n.s. & 0.007 & 0.01 \\
\hline TGFB3 & Transforming growth factor, beta 3 & 7,87 & 7,63 & 8,14 & n.s. & n.s. & 0.07 \\
\hline TMED1 & $\begin{array}{l}\text { Transmembrane emp24 protein transport domain } \\
\text { containing } 1\end{array}$ & 8,03 & 8,16 & 7,55 & n.s. & n.s. & 0.05 \\
\hline TNFRSF9 & $\begin{array}{l}\text { Tumor necrosis factor receptor superfamily, } \\
\text { member } 9\end{array}$ & 10,17 & 9,78 & 11,02 & n.s. & 0.06 & 0.01 \\
\hline
\end{tabular}

